\title{
"A rua era das negras e dos negros" - Os ganhadores que pararam Salvador
}

\author{
"The street was filled with Black women and Black men"- The winners who \\ stopped Salvador \\ "La calle era de las negras y de los negros" - Los ganhadores que pararon Salvador
} Renata Figueiredo Moraes*

REIs, João José. Ganhadores: a greve negra de 1857 na Bahia. São Paulo: Companhia das Letras, 2019. 452p.

O livro Ganhadores: a greve negra de 1857 na Babia foi lançado em agosto de 2019 e preenche uma importante lacuna da historiografia a respeito das greves promovidas por escravos ou libertos. Como homens e mulheres escravizados viveram o cotidiano da escravidão urbana? $\mathrm{O}$ autor, João José Reis (UFBA), especialista em contar como os escravos se revoltavam, nos oferece uma riqueza de detalhes sobre a vida desses homens que resistiram a uma maior exploração dos seus corpos numa grande cidade escrava. O final da história está no título do livro e representa o nome dado a esses homens que ousaram contra a municipalidade soteropolitana: ganhadores, pois também venceram uma batalha que durou 10 dias e que paralisou a cidade de Salvador. Além deles, com esse livro ganharam todos os interessados em discutir a escravidáo, o trabalho, a liberdade e a cidadania negra no oitocentos.

O livro, dividido em 15 capítulos, trata de como os trabalhadores escravizados, em sua maioria africanos, iniciaram uma greve que pretendia eliminar as exigências impostas pela municipalidade de Salvador para fazer o ganho nas ruas: uma matrícula e o uso de uma chapa de metal numerada, tudo sob o custo de 5 mil réis. De acordo com o autor, essa quantia correspondia a quase 15 quilos de carne, um valor alto, principalmente para o ganhador que possivelmente arcaria com o pagamento dessa licença. A repulsa pela obrigatoriedade do uso da placa de metal pelo africano também era uma forte causa para a mobilização. As posturas que regulamentaram tal exigência partiram da Câmara

DOI: http://dx.doi.org/10.1590/2237-101X02204715

Resenha recebida em 3 de abril de 2020 e aceita para publicação em 5 de agosto de 2020.

* Professora da Universidade do Estado do Rio de Janeiro, Instituto de Filosofia e Ciências Humanas, Rio de Janeiro/ RJ - Brasil. E-mail: renatafm2003@yahoo.com.br. ORCID: https://orcid.org/0000-0003-01179826. 
Municipal, importante instância administrativa e de regulação das cidades no tempo do Império (TERRA, 2019, p. 157), que de certo modo também organizava o cotidiano da escravidão, explorada por Reis no seu primeiro capítulo. A reação dos ganhadores foi a partir de uma segunda-feira, $1^{\circ}$ de junho de 1857, primeiro dos dez dias de paralisação. É a partir dessa ação que o autor esmiúça a escravidão urbana em Salvador logo nos anos seguintes ao fim do tráfico de escravos (1831). A cidade parecia ainda viver o fantasma da Revolta dos Malês (1835), quando escravos africanos foram reprimidos violentamente ao iniciarem uma grande insurreição, também objeto de estudo do autor. A saga dos ganhadores aconteceu mais de duas décadas depois, sendo mais abrangente e sem repressão violenta. Importante ressaltar que as causas para essa paralisação partem das pretensóes das autoridades soteropolitanas de desafricanizar a cidade de Salvador, ao impor a esses trabalhadores pesadas taxas sobre seus trabalhos e as licenças para o ganho, além de controlar essa população no espaço público, tanto no labor quanto no lazer, por conta da iminência de um motim, crença de senhores e autoridades.

Importante ressaltar que essa grande mobilização dos trabalhadores escravizados explorada por Reis em seu livro também pode ser encontrada em outras cidades, mas não tendo tido ainda um estudo aprofundado. Flavio Gomes e Antonio Luigi Negro discutiram de forma breve as paredes, ações perpetradas por escravizados a fim de reivindicar mudanças ou evitar deslocamentos (2013). Tais ações lembram as greves de tra- balhadores livres que eram constantes também no Rio de Janeiro e por diferentes motivos. João Reis ao longo do seu livro pontua a mobilização de africanos, escravizados ou não, a fim de reivindicar maiores espaços de atuação em suas atividades ou como forma de solidariedade entre seus pares. Nesse aspecto, o autor ressalta que tais açóes que hoje podemos chamar de "grevistas" (nome francês para a paralisação das atividades laborais) não possuíram inspiraçóes em qualquer movimento europeu. Desse modo, em diálogo com o texto de Negro e Gomes, o livro de Reis reforça a necessidade de ampliarmos o olhar sobre as açóes dos escravizados e suas paralisaçóes que não necessariamente reivindicavam a liberdade. A forma como os trabalhadores do pós-abolição se serviram dessa experiência de mobilização precisa ainda ser alvo dos historiadores do mundo do trabalho, e o livro de Reis indica os caminhos para esse estudo.

A denominação "ganhadores" é um grande guarda-chuva para designar a ocupação desses homens, em sua maioria africanos e escravizados, e que atuavam em diversas atividades que garantiam o funcionamento da cidade. No capítulo 2, o autor trata desses trabalhadores e a divisão da sociedade de Salvador no ano da greve, quando os escravos eram quase $40 \%$ do total da população de uma cidade que era prioritariamente negra e que contabilizava $70 \%$ com os demais negros livres e libertos. $\mathrm{O}$ grupo de ganhadores dominava a região portuária da cidade e era responsável pelo carregamento de mercadorias que chegavam ao porto ou que eram transmitidas para outras pessoas. A pa- 
ralisação desse serviço representava também a interrupçáo de um cotidiano numa cidade cheia de ladeiras e com senhores e senhoras indispostos a subi-las sobre seus próprios pés e que utilizavam esses ganhadores para subir e descer as ladeiras da antiga capital. O uso de negros como meios de transporte foi registrado pelos viajantes que também passaram pelo Rio de Janeiro, conforme lembra Paulo Terra em um artigo recente (2019, p. 163). Apesar do seu valor para as cidades escravas, esses ganhadores eram constantemente associados ao perigo e à criminalidade, sendo depreciados nas suas atividades, tanto em Salvador como no Rio de Janeiro. Para esse ponto eu friso que náo era muito diferente do que acontecia no Rio de Janeiro, quando um jornal escrito por trabalhadores, o Tribuna Artística, considerava uma afronta um trabalhador livre ganhar igual a um preto de ganho (Rio de Janeiro, 10/12/187). O livro de Reis também levanta uma discussão importante para o oitocentos que é a respeito do cotidiano do trabalho do liberto, que não está dissociado de uma lógica que vem da escravidão e que é controlado pelos escravos. $\mathrm{Ou}$ seja, ser liberto numa cidade prioritariamente escrava talvez aproximasse muito mais esse sujeito do escravizado do que do livre. Nesse ponto, o mercado de trabalho também daria sinais do quanto que a marca da escravidão ficaria presente nessa vida em liberdade.

Os ganhadores da Bahia estavam organizados em cantos, regióes regulamentadas pela Câmara municipal e conhecidas pelos moradores, e compostos por um número específico de homens e com algumas mulhe- res, tema já tratado pelo autor em um artigo anterior (2000). Neste novo livro, ele parte dos cantos para caracterizar os que estavam nas ruas fazendo o ganho. Essas áreas, além de serem uma estação de trabalho, tornaram-se um nicho cultural e a identidade étnica favoreceu a resistência e a negociação entre senhores, libertos e africanos escravizados, de maioria nagô. No tempo da greve, o autor identificou nesses lugares mais combatividade dos seus membros do que em associações de ajuda mútua, mesmo as irmandades negras, por exemplo. Importante ressaltar a existência de "juntas de crédito" africanas ligadas aos cantos e que poderiam servir para a compra de alforrias ou outros fins (p. 86), o que também dava a esses nichos uma experiência de associativismo singular e náo muito distante das existentes em outras regiôes não escravistas. Marcel Van Der Liden (2013), no seu estudo sobre os trabalhadores, identificou associações que possuíam um sistema de crédito que servia para a cobertura individual dos seus membros que contribuíam com uma quantia específica para ser usada em caso de doença ou outro mal (p. 104), algo parecido foi identificado por Reis para Salvador desde os tempos dos Malês, sendo também de conhecimento das autoridades da cidade baiana. Essa ideia associativa dá uma dimensão maior não apenas a esse grupo de trabalhadores reunidos nos cantos, escravizados ou não, como demonstra que já pareciam organizados a partir de uma lógica própria, que poderia ser racial, étnica ou a partir do status jurídico ao qual pertenciam. Apenas entendendo os cantos como uma organizaçáo complexa que conseguimos com- 
preender como os trabalhadores de ganho se mobilizaram a fim de paralisarem por dez dias as suas atividades. Como forma de controlar esses trabalhadores e seu pertencimento, após a greve a municipalidade exigiu os registros dos seus componentes, sendo essa uma valiosa fonte usada por Reis para tratar de diferentes aspectos da escravidão urbana de Salvador. Interessante seria um mapa identificando os cantos, suas proximidades a fim de que um leitor de fora da Bahia tivesse a noção da distância espacial entre eles e seus impactos na organizaçáo do trabalho escravo na regiáo portuária de Salvador, assim como uma imagem da ficha usada para a matrícula dos ganhadores.

Algumas décadas anteriores à greve, a municipalidade de Salvador já havia tentado estabelecer algumas intervençóes sobre os cantos, não deixando de haver por parte dos ganhadores uma resistência a isso, tornando-se evidente como o legislador não conhecia a força das ruas vinda desses trabalhadores. Ou seja, as medidas de 1857 e que provocaram a greve foram ensaiadas por vereadores e chefes de polícia anos antes. Uma das açôes era inviabilizar a permanência dos africanos libertos em Salvador, que mesmo sendo maioria na Bahia, não pertenciam a nenhum projeto de liberdade ou de cidadania desde 1824, quando a Constituição não deu a eles o direito à cidadania, apesar de libertos e livres. Ao africano não era permitido se naturalizar, apenas trabalhar, de preferência escravizado e na lavoura, conforme pretendiam as autoridades soteropolitanas. Isso deixa evidente o grande problema da cidade escravista do século XIX: a existên- cia de africanos libertos. A cidade náo seria para eles, não no gozo da sua liberdade conquistada por diferentes meios. Se o Haiti assombrava os grandes senhores de escravos, as autoridades soteropolitanas tinham seu próprio fantasma: a Revolta dos Malês. Mais de 20 anos depois dos malês, a cidade viu-se ainda africanizada e dependente dos serviços prestados por esses africanos. $\mathrm{O}$ que deu errado no projeto de desafricanizaçáo que as autoridades de Salvador pareciam ter empreendido a partir de 1835? Uma hipótese talvez seja o próprio tráfico de escravos que continuou ilegal e a dependência do trabalho escravo, fazendo com que a entrada de africanos se intensificasse ainda mais depois de 1837, demonstrando a força da escravidáo, conforme trata Sidney Chalhoub em seu último livro (2012). Possivelmente, grande parte dos africanos que promoveram a greve de 1857 fosse ilegal, ou seja, tendo entrado em Salvador após o fim do tráfico, em 1831. Após libertos, esses africanos tornaram-se o novo inimigo das autoridades, fruto de uma ação que Reis chama de "política africanofóbica”. A esse respeito, vale citar o próprio autor, no capítulo 7 , quando trata mais especificamente da greve:

O preconceito ("prejuízo") contra o africano, e náo apenas o escravizado, era então generalizado, um dado da estrutura mental da classe trabalhadora livre nacional - na maioria negros, aliás -, herança cotidianamente alimentada, esclareceu o periódico. Náo se tratava de repulsa de cor (ou racial, se preferirem) nem de classe, mas étnica, uma espécie 
de xenofobia crioula historicamente acicatada pela elite senhorial por meio de uma política de favorecimento aos escravos nascidos no Brasil. Não surpreende que os africanos também se protegessem por detrás de barreiras étnicas (REIS, 2019, p. 180. Grifos do autor).

Essa afirmação a respeito de uma repulsa pelo africano se repetiu no pós-abolição, não tendo mais o africano de fato, a repulsa se tornou pela cor desse trabalhador. Tal perspectiva nos leva a pensar no pós-abolição e na reconstrução de uma lógica de trabalho que ultrapassasse a criada para a escravidão. No entanto, parece que mesmo após mais de 130 anos da abolição temos alguns ofícios destinados a um perfil de trabalhador, e não é à toa que grande parte dos vendedores ambulantes e informais que ganham as ruas seja de homens e mulheres negros. A liberdade da abolição não deu liberdade ao trabalho também.

A cidade de Salvador não parece ser diferente das outras cidades do Império, dependentes do trabalho de homens e mulheres africanos, libertos ou não. Somado a isso, Reis ainda mostra os esforços para favorecer o "imigrante branco" e o asiático, havendo inclusive um vereador empenhado no negócio. Ou seja, não era contra apenas os africanos ou os estrangeiros como um todo, mas sim contra a negritude e um passado escravista que deveria ser eliminado ainda no período em que a escravidão é forte e defensável. Nos capítulos seguintes, após a ação grevista, o autor trata do vestígio dessa ação para a cidade de Salvador, principalmente no que se refere às açóes da municipalidade contra o africano. Importante ressaltar que, após a década de 1870, o número de africanos na escravidão urbana de Salvador é reduzido, o que leva também a um esforço, segundo o autor, de reduzir também a escravidão urbana na cidade, onde haveria um incentivo para que homens pobres livres substituíssem os africanos no transporte de mercadorias, principalmente após a Guerra do Paraguai. No entanto, no projeto de embranquecimento da cidade através da imigração, Salvador não saiu vitoriosa. Segundo Reis, quem substituiu os ganhadores africanos foram os negros e mestiços brasileiros, vindos de fora de Salvador, tornando-se o ganho a porta de entrada de migrantes para o trabalho na cidade.

Um ponto essencial desta obra são as fontes utilizadas pelo autor. Ao mesmo tempo em que extrai de um livro de matrículas feito entre 1887 e 1889 inúmeras informações sobre os ganhadores nas vésperas da abolição e de Salvador por conta da identificação dos cantos, ele também nos ensina a usar diferentes fontes para identificar escravos e seus senhores. Ao fazer isso, o autor monta um cenário da escravidão urbana entre escravos, senhores e autoridades e como estáo relacionados, de difícil separação. Outro ponto importante foi a ausência de registro das reivindicações dos grevistas. Ou seja, uma paralisação silenciosa fez barulho na Câmara, na Associação Comercial e, principalmente, em toda a cidade. Apesar dessa ausência o autor consegue esclarecer as reivindicaçôes dos ganhadores paralisados. Por outro lado, nos oferece a discussão sobre o apagamen- 
to desse episódio no ano seguinte, nos discursos de políticos de Salvador. Tal apagamento seria para não dar protagonismo aos africanos na mudança gerada na legislação após uma ação tão forte como a greve? Essa questáo nos faz lembrar do apagamento das outras açóes grevistas do horizonte de interesse da historiografia que estuda o trabalho, que também esquece o século XIX no Brasil e desconsidera os escravos e ex-escravos como trabalhadores e agentes dessas açóes. Ao chamar esses escravizados de trabalhadores, o autor está pontuando que eles devem estar no campo de estudo de pesquisadores do mundo do trabalho.

Esta obra é uma importante contribuição para os estudos sobre escravidão urbana no Brasil. João José Reis destacou a especificidade da escravidão urbana e o uso da rua para a realização do trabalho, em que o tempo do senhor e o tempo do escravo eram investidos no trabalho. A atenção ao escravo na rua já tinha sido dada pela historiografia desde a década de 1980 com os livros $\mathrm{Ne}$ gro na rua, de Marilene Rosa Silva e $O$ feitor ausente, de Leila Algranti, ambos de 1988. Essas duas obras foram pilares para entender a importância da escravidão urbana para o Império e serviram para que outros historiadores entendessem as peculiaridades do escravo nas ruas das cidades imperiais. No entanto, esta obra de Reis vai além ao colocar esse negro, escravo ou não, na rua como um sujeito de uma ação de resistência não apenas à escravidão, mas à organização do seu trabalho. Nesse ponto, o livro servirá para aqueles que estudam o mundo do trabalho antes da abolição, quando a or- ganização dos trabalhadores já era possível de ocorrer. Com esta obra conseguimos não apenas entender a greve de 1857, que já tinha sido objeto de um artigo do autor, como também ter uma dimensão da forma como a cidade de Salvador reuniu características que tornaram possível uma greve desse porte. Para os estudiosos do pós-abolição o livro oferece boas discussões, uma vez que indica causas dos problemas enfrentados pelos ex-escravos ainda durante a escravidão e que não foram superados pela lei assinada no 13 de maio. Ou seja, o autor não tratou apenas dos ganhadores, mas também dos vencidos, muitos homens e mulheres africanos que não puderam vencer as batalhas que lutaram contra a escravidão. Apesar disso, a rua era das negras e dos negros, conforme viu Reis em Salvador. Que esta obra nos inspire a ver os negros e negras de outras cidades nos tempos da escravidão e do pós-abolição.

\section{Referências}

ALGRANTI, Leila. O feitor ausente. Estudo sobre a escravidão urbana no Rio de Janeiro. Petrópolis/RJ: Editora Vozes, 1988.

CHALHOUB, Sidney. A força da escravidão. Ilegalidade e costume no Brasil oitocentista. São Paulo: Companhia das Letras, 2012. LINDEN, Marcel Van. Trabalhadores do mundo: ensaios para uma história global do trabalho. Campinas, SP: Editora da Unicamp, 2013.

NEGRO, Antonio Luigi; GOMES, Flávio dos Santos. As greves antes das greves: as paralisações do trabalho feitas por escravos 
no século XIX. Ciência e Cultura, v. 65, n. 2, São Paulo, abr./jun. 2013.

REIS, João José. A greve negra de 1857 na Bahia. Revista USP, n. 18, p. 6-29, 1993. REIS, João José. De olho no canto: trabalho de rua na Bahia na véspera da abolição. AfroÁsia, n. 24, p. 199-242, 2000.

REIS, João José. Ganhadores: a greve negra de 1857 na Bahia. São Paulo: Companhia das Letras, 2019.
SILVA, Marilene Rosa Nogueira. Negro na rua. A nova face da escravidão. Sáo Paulo: Editora Hucitec, 1988.

TERRA, Paulo. Câmaras municipais no Império: as posturas municipais do Rio de Janeiro sobre o trabalho (1830-1838). In: TERRA, P; MAGALHÃES, M; ABREU, M. (orgs). Os poderes municipais e a cidade: Império e República. Rio de Janeiro: Mauad X, 2019. 